\title{
CULTIVATION OF THE GENUS PELARGONIUM UNDER GLASS
}

\author{
Kate Hughes ${ }^{l}$
}

\begin{abstract}
This paper describes the cultivation under glass of the genus Pelargonium. The difference between pelargonium and the other four genera in the family Geraniaceae is noted and a list of species grown at the Royal Botanic Garden Edinburgh is provided. The use of the genus in the display glasshouses at this botanic garden is described followed by notes on cultivation including watering, nutrition, pruning, pest control, and propagation. The use of pelargoniums in the commercial and medicinal industries follows.
\end{abstract}

\section{INTRODUCTION}

It is unclear exactly how many species of pelargonium there are but it is agreed that there are over 250 (Bakker et al., 2000). Within the genus there is a huge variety of growth forms and habits from large sub-shrubs with bright showy flowers, to small annuals, tiny geophytes with barely-visible leaves and flowers and thick-stemmed succulents. Almost all pelargoniums come from the south western corner of southern Africa. However, the distribution of the genus spreads up the east coast of Africa as far as the Arabian Peninsula to the Soqotra archipelago and Syria as well as Turkey. There are also a small number of representatives in Australia, New Zealand, and the islands of Madagascar, Tristan da Cunha and St. Helena. This paper describes the main cultivation techniques for the sections of the genus Pelargonium.

\section{TAXONOMY}

The genus Pelargonium is in the family Geraniaceae which has included many genera in the past but many botanists now agree that it should contain just five - Geranium, Pelargonium, Erodium, Monsonia, and Sarcocaulon (Fig. 1). Many interested but unaware people ask 'What is the difference between a pelargonium and a geranium?' The difference between pelargonium and the other four genera can be easily summarized by the shape and structure of the flowers. Pelargoniums have zygomorphic (not symmetrical across horizontal and vertical axes) flowers with a nectar tube which is called a hypanthium. The other genera have actinomorphic flowers (symmetrical all the way around) without nectar tubes (See Fig. 1). The differences between the other four genera lie in the numbers of fertile stamens and

${ }^{1}$ Kate Hughes is Horticultural Project Officer and Sub Editor of Sibbaldia at the Royal Botanic Garden Edinburgh. From 2001 to 2009 she was an Indoor Horticulturist with responsibility for the care of the pelargonium collection, ginger collection and Ferns and Fossils display house.

Address: 20A Inverleith Row, Edinburgh, EH3 5LR.

Email: k.hughes@rbge.org.uk 


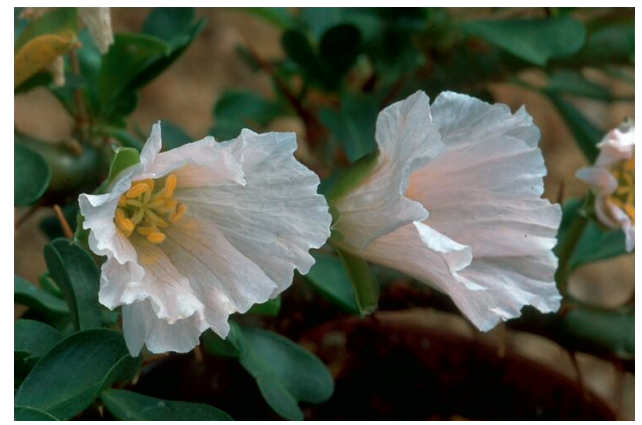

Fig. 1 Sarcocaulon vanderetiae, an actinomorphic flower. Photo: Debbie White.

their growth habit. Van der Walt (1977) has summarized these in the key reproduced below (Fig. 2).

1 Flowers actinomorphic and without a nectar spur

2 Stamens 10

3 Fertile stamens $10 \ldots \ldots \ldots$.

Geranium

3 Fertile stamens $5 \ldots \ldots \ldots$.

Erodium

2 Stamens 15

4 Stems herbaceous without spines ..........

Monsonia

4 Stems succulent, generally with spines .........

Sarcocaulon

1 Flowers zygomorphic with a nectar spur ..........

Fig. 2 Key to the five genera in Geraniaceae reproduced from van der Walt (1977).

The genus is divided into 16 sections (Bakker et al., 2000) and this paper follows his work. These sections are largely based on the first major work on the genus Pelargonium by van der Walt (1977). The classification of these is based largely on morphology, chromosome number, and supported by molecular data. The distinctions between them also reflect the differences in growth form and, to some extent, their area of distribution. The sections can therefore be grouped together for the purposes of their cultivation as well as taxonomy.

The pelargonium collection at RBGE contains species from each of the sections as listed below.

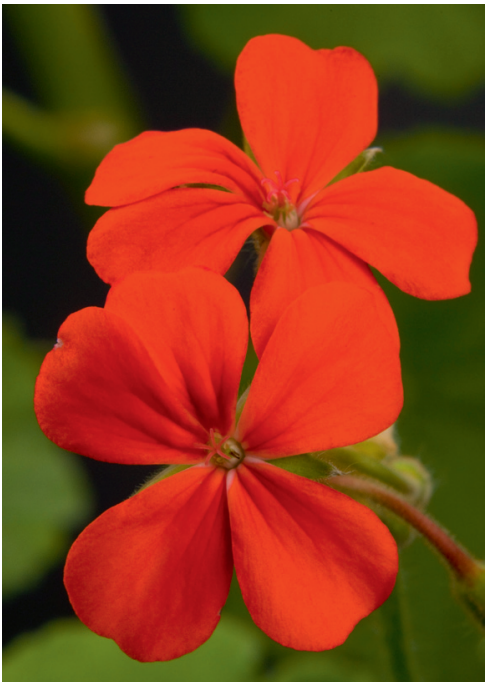

Fig. 3 Pelargonium inquinans, 'Scarlet geranium'. Photo: Lynsey Wilson. 
Camplyia

Pelargonium elegans

P. ovale

P. tricolor

Ciconium

P. acetosum

P. alchemilloides

P. acreaum

P. elongatum

P. frutetorum

$P$. inquinans

P. multibracteatum

P. mutans

P. peltatum

$P$. ranunculophyllum

P. tongaense

P. transvaalense

P. zonale

Chorisma

P. mollicomum

Cortusina

P. appendiculatum

P. cortusifolium

P. crassicaule

P. desertorum

P. echinatum

P. fragrans

P. glechomoides

P. magentum (syn. $P$. rhodanthum)

P. xerophyton

Hoarea

P. aristatum

P. bubonifolium

P. caroli-henrici

P. fasciculaceum

P. fissifolium

$P$. heracleifolium

P. longifolium
P. luteolum

P. nervifolium

P. oblongatum

P. pillansii

$P$. punctatum

P. rapaceum

Isopetalum

P. cotyledonis

Jenkinsonia

$P$. endlicherianum

P. mutans

P. tetragonum

P. praemorsum

P. quercetorum

Ligularia

P. articulatum

P. fulgidum

P. hirtum

P. mollicomum

P. otaviense

P. pulchellum

P. stipulaceum

P. sericifolium

P. trifidum

Magnistipulacea

P. bowkeri

P. caffrum

P. luridum

P. schizopetalum

Myrrhidium

P. longicaule

P. myrrhifolium

P. suburbanum

Otidia

P. alternans 


$\begin{array}{ll}\text { P. carnosum } & \text { P. tomentosum } \\ \text { P. ceratophyllum } & \text { P. vitifolium } \\ \text { P. crithmifolium } & \text { P. 'Viscosissimum' } \\ \text { P. dasyphyllum } & \\ \text { P. klinghardtense } & \text { Peristera } \\ \text { P. laxum } & \text { P. australe } \\ \text { P. paniculatum } & \text { P. inodorum } \\ \text { P. rotundipetalum } & \\ & \text { Polyactium } \\ \text { Pelargonium } & \text { P. gibbosum } \\ \text { P. betulinum } & \text { P. lobatum } \\ \text { P. candicans } & \text { P. multiradiatum } \\ \text { P. capitatum } & \text { P. pulverulentum } \\ \text { P. cordifolium } & \text { P. radulifolium } \\ \text { P. cucullatum } & \text { P. triste } \\ \text { P. denticulatum } & \\ \text { P. grandiflorum } & \text { Reniformia } \\ \text { P. graveolens } & \text { P. abrotanifolium } \\ \text { P. hispidum } & \text { P. album } \\ \text { P. laevigatum } & \text { P. exstipulatum } \\ \text { P. lanceolatum } & \text { P. fragrans } \\ \text { P. panduriforme } & \text { P. ionidiflorum } \\ \text { P. patulum } & \text { P. odoratissimum } \\ \text { P. papilionaceum } & \text { P. reniforme } \\ \text { P. pseudoglutinosum } & \text { P. sidoides } \\ \text { P. quercifolium } & \\ \text { P. radens } & \text { Subsucculentia } \\ \text { P. sublignosum } & \text { P. karooicum } \\ & \end{array}$

\section{GEOGRAPHY AND DISTRIBUTION}

The majority of the African species which are the most popularly grown in Europe and the Americas are from the most westerly corner of the Cape of South Africa which experiences winter rainfall. Bakker et al. (1999) provide an excellent map of the distribution of pelargonium species in relation to the rainfall areas of South Africa. It shows the high concentration of species in the winter rainfall area; in one example 70 species per square degree (Bakker et al., 1999). The very commonly grown scarlet Pelargonium inquinans ('Scarlet geranium') (Fig. 3) is from the southern Cape which has this winter rainfall pattern.

Some species such as P.reniforme (Fig. 4) and P. sidoides, grow towards the east and north of the Cape where the climate is characterized either by summer or all-year-round 
rainfall. The soils on which pelargoniums occur are very free-draining (Fig. 6 ), in some cases it is the pure sand of the Namib Desert and this is where species such as $P$. fulgidum and $P$. gibbosum (Fig. 5) are found, or on beaches of the southern-most tip of South Africa or in the crevices of rocks (Fig. 7). It is the geography of their native environment which gives the best clues to the needs of plants in cultivation. By observing the patterns of rainfall, soil types and associated vegetation, horticulturists can learn much about how best to make the plants perform in cultivation.

Species in section Hoarea perrenate through the hot dry summer months as small tubers. Some, such as $P$. bubonifolium, P. fergusoniae (Fig. 13) or $P$. aristatum, are no more than $10 \mathrm{~mm}$ in diameter when young. When tempera-

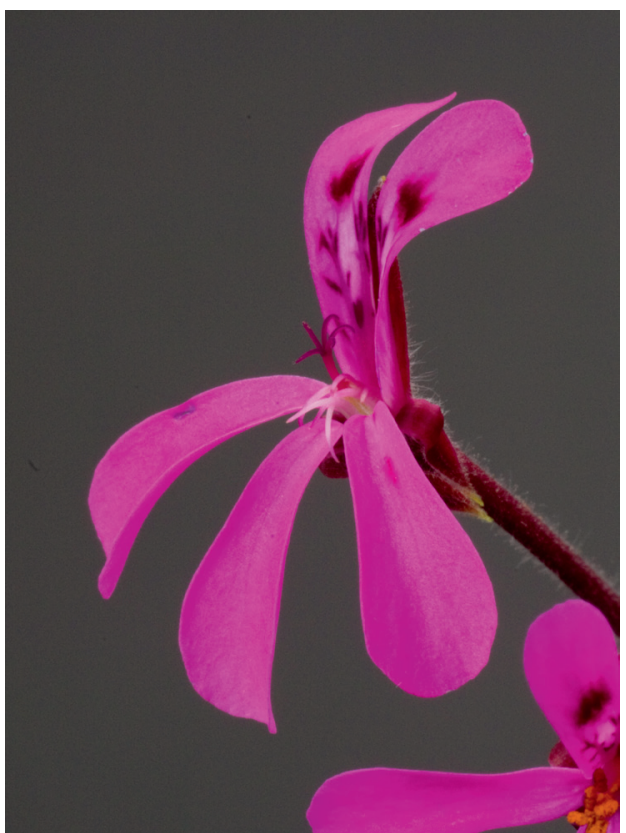

Fig. 4 Pelargonium reniforme, grows in the all-yearround rainfall area of South Africa. Photo: Lynsey Wilson. tures drop and rains arrive in winter, small leaves emerge and the plant grows. When the temperatures begin to rise again and the sandy soils dry out, the leaves die back and flower stems emerge.

Species in sections Cortusina, Isopetalum, Ligularia, Polyactium and Subsucculentia also follow this pattern. These sections are referred to as winter-growing pelargoniums and it is important to be aware of these seasonal changes in growth when cultivating them.

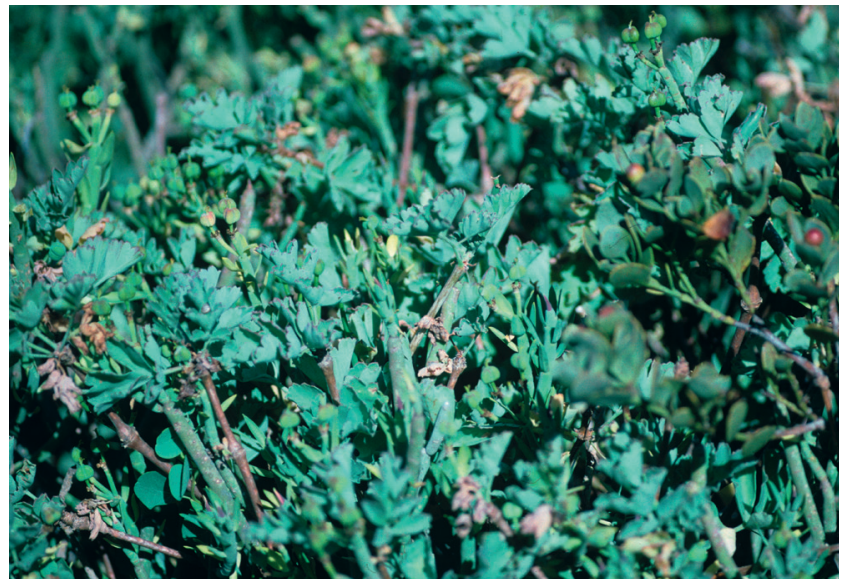

Fig. 5 Pelargonium gibbosum, showing the glaucous leaves, growing through a succulent member of Euphorbiaceae for support for the long stems. Photo: Kate Hughes. 

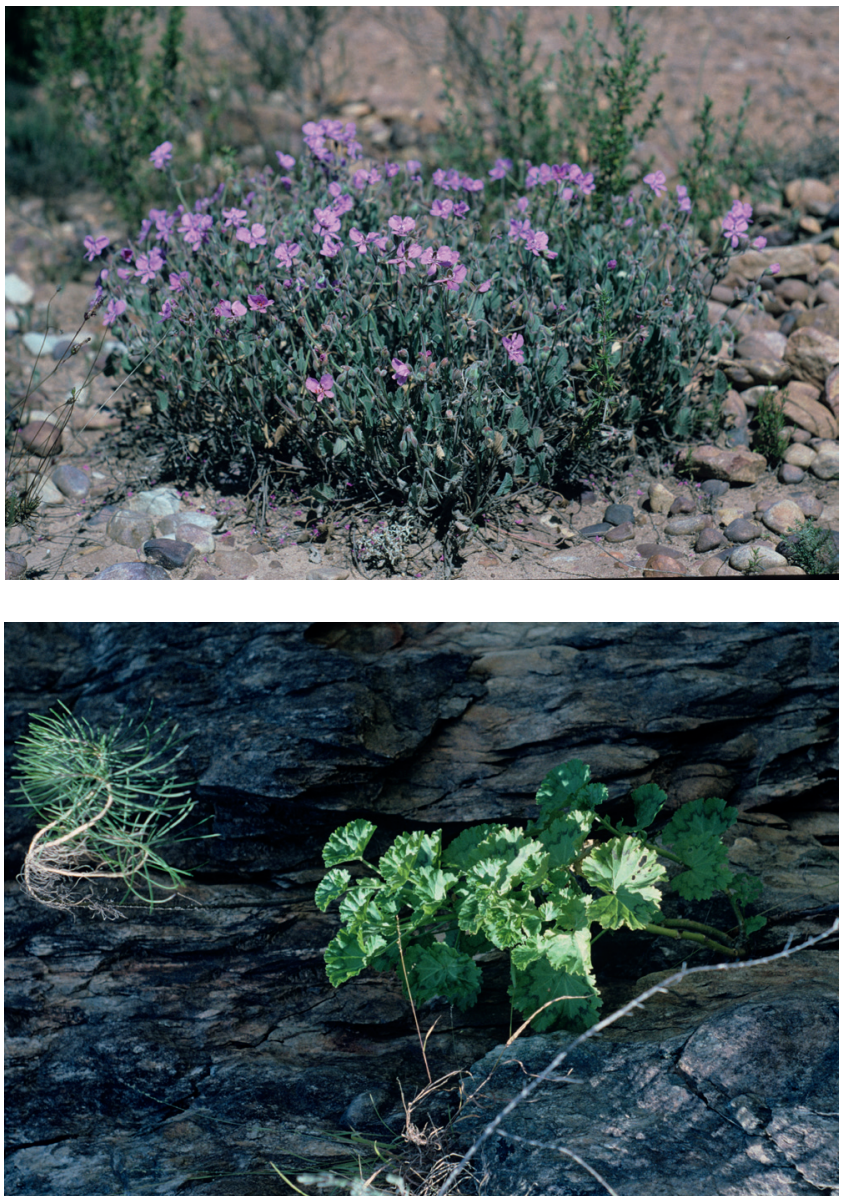

Fig. 6 Pelargonium ovale in Bontebok National Park, South Africa. Photo: Kate Hughes.

Fig. 7 Pelargonium zonale growing in a rock crevice on the road to the Cango caves, South Africa. Photo: Kate Hughes.

Some species occur at higher elevations in habitats where more water and shade is available, such as the sub-shrub $P$. hispidum and succulent-stemmed herb $P$. transvaalense. These plants have large leaves. Reports of $P$. papilionaceum attaining an unusually great height of $2 \mathrm{~m}$ with 'leaves the size of dinner plates' (F. Powrie, pers. comm.) were attributed to the fact that the plant was growing in a shady gully with a continuous supply of water. The plants will grow to unusual proportions if provided with more resources than they are adapted to cope with.

One observation that the author made on a visit to South Africa in 2004, is that while the environments in which pelargoniums occur vary from coastal to inland, sea level to high altitude, winter rainfall to summer rainfall, exposed to shady crevices, the substrate in which their roots are established is always very free-draining. This can vary from sand to quartzite soils but if lifted they always have very large particles through which rain will penetrate easily and thus dry out easily. This should also be remembered when propagating and cultivating the plants. 


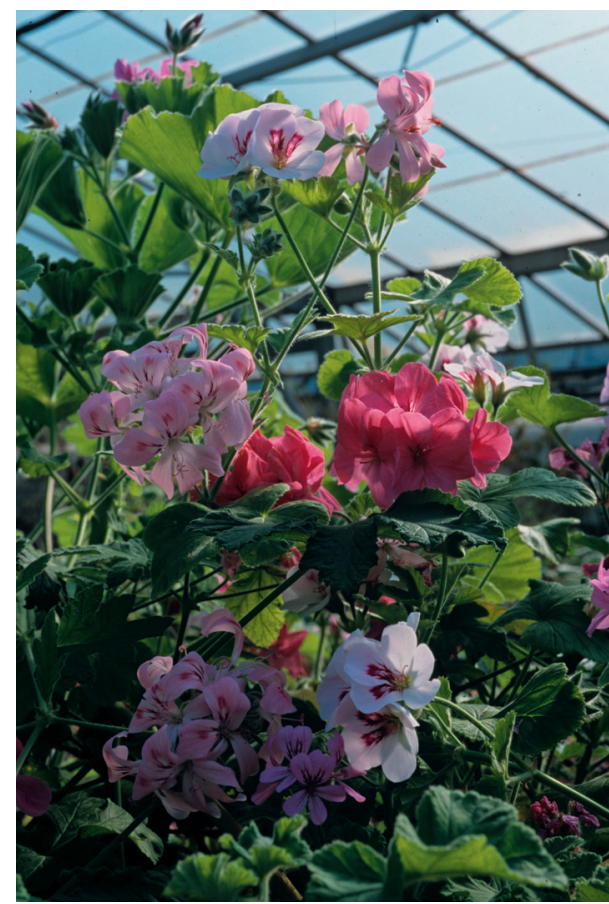

Fig. 8 A selection of cultivars used for public display at RBGE. Photo: Debbie White.

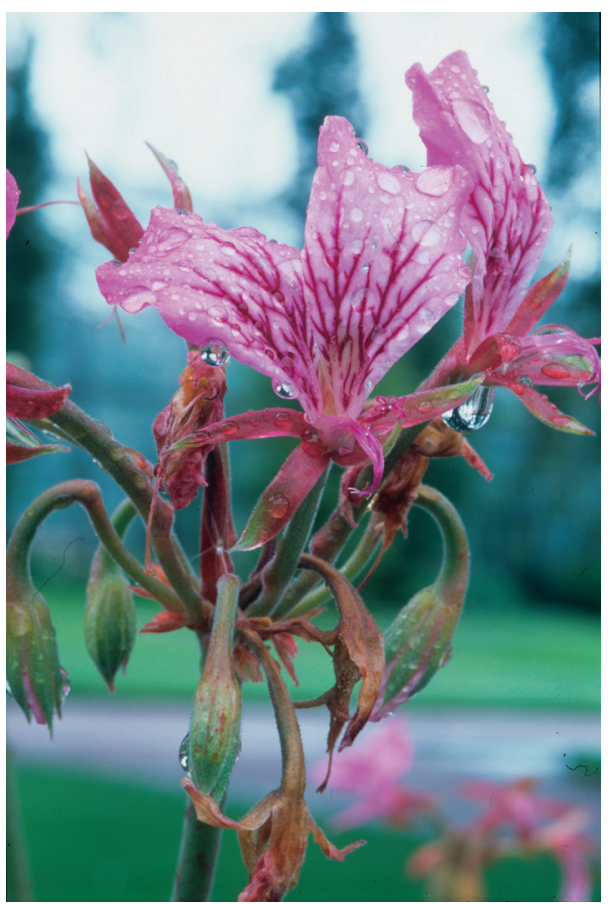

Fig. 9 Pelargonium endlicherianum growing in the Alpine Yard, RBGE. Photo: Debbie White.

\section{CULTIVATION AND USE IN BOTANIC GARDENS}

Most of the collection came to the Royal Botanic Garden Edinburgh (RBGE) in 2000 when Mary Gibby was appointed Director of Science at RBGE and brought her research collection from Chelsea Physic Garden. Professor Gibby had built up the collection largely from wild origin material over the previous fifteen years when she was studying the group as a staff member at the Natural History Museum, London, and working closely with the pelargonium research group in Stellenbosch, South Africa.

The variety of growth habits and foliage and range of brightly coloured flowers make them ideal for colourful displays (Fig. 8). Many pelargoniums are recognizable to the public but some groups, particularly the winter-growing species and those adapted to very dry environments, are less familiar. It is this variety that can provide a useful message about 'everyday', well-known plants which have relatives which contribute to some of the more extreme habitats in the world and that these habitats and the biodiversity they support are also important.

At RBGE, pelargoniums are planted out for display in three temperate glasshouses and Pelargonium endlicherianum, the only truly hardy species, which occurs in Turkey, is planted in the borders in the Alpine Yard (Fig. 9). The temperate glasshouses are 


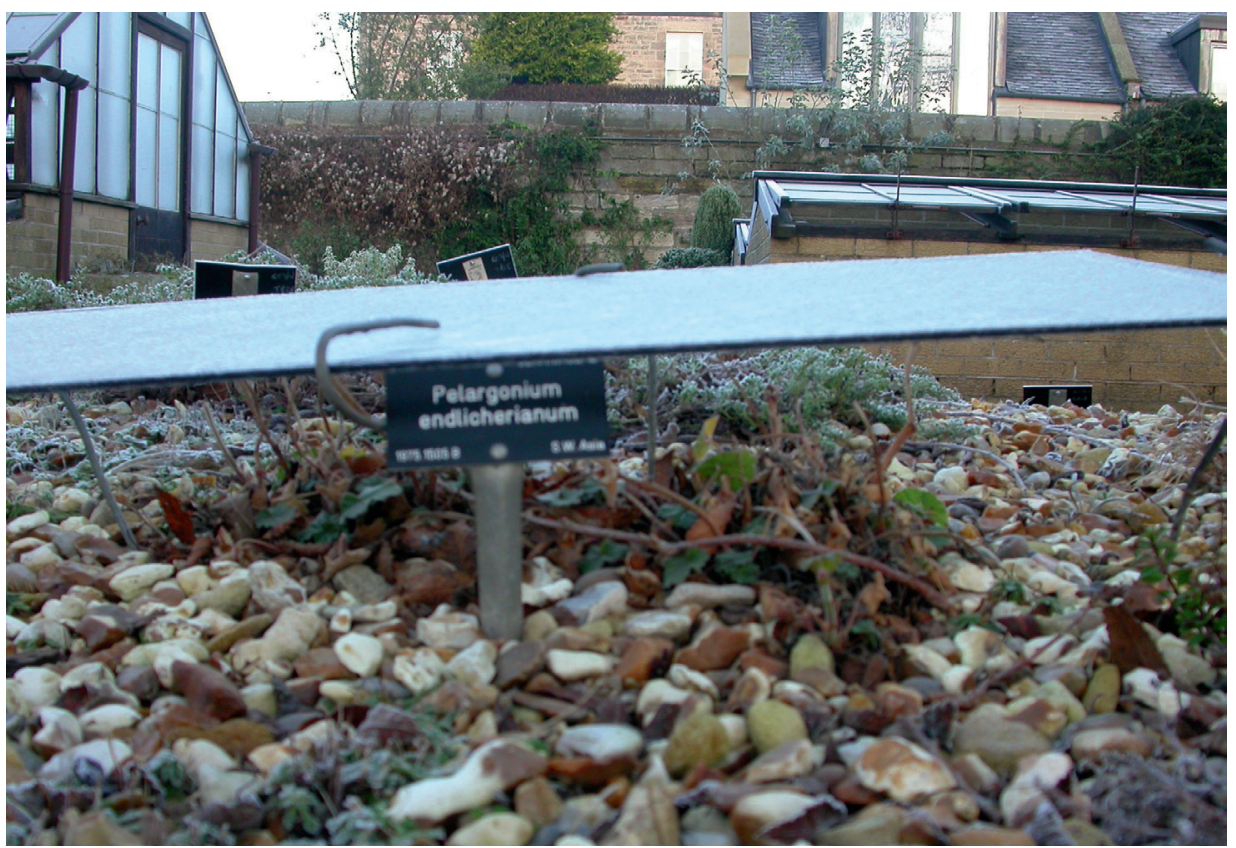

Fig. 10 Pelargonium endlicherianum in winter covered with glass sheet for protection. Photo: Kate Hughes.

heated to a maximum of $16^{\circ} \mathrm{C}$ and the Alpine borders experience the temperatures of the usual Scottish seasons. A sheet of glass is suspended with wire stands over the dormant stems of $P$. endlicherianum through the winter months to prevent damage from damp and frost (Fig. 10). Trials involving the use of some of the larger sub-shrubby species such as $P$. hispidum in the borders around the glasshouses have been undertaken, however, these plants have not done well. It seems that it is not warm enough for them. Species used for public display are listed.

\section{Arid Lands House}

Pelargonium species planted: Pelargonium capitatum, P. crassicaule, P.crithmifolium, $P$. gibbosum, $P$. papilionaceum, $P$. triste, and $P$. zonale.

Pelargoniums are used as part of the 'South Africa' section, primarily to demonstrate the drought tolerance of the species planted and the growth forms which arise in very arid conditions. The plants in this section are mainly winter-growing and they therefore provide a winter display when other plants in other areas of the glasshouse are not actively growing. They are also compatible with the other drought tolerant genera planted there, such as Aloe, Gasteria, and Haemanthus and the arid landscaping of the glasshouse. $P$. papilionaceum, which grows to $2 \mathrm{~m}$ and occurs in more humid and shady areas provides height and flower colour along with some other larger plants in this section such as the tree-like euphorbias, Euphorbia obovalifolia and E. candelabrum. 


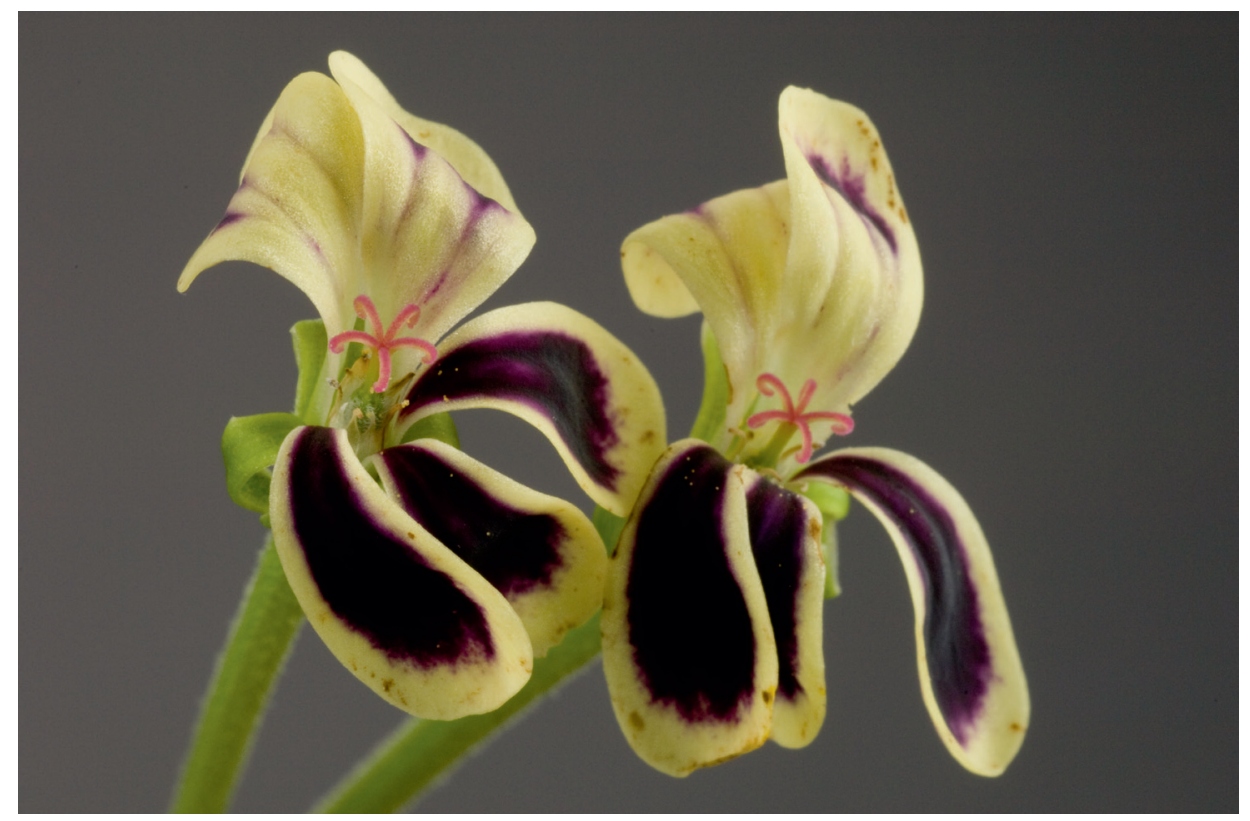

Fig. 11 Pelargonium pulverulentum. Photo: Lynsey Wilson.

\section{Main Temperate House}

Pelargonium species planted: $P$. tomentosum, . cucullatum ssp. strigifolium, P. quercifolium, P. tricuspidatum.

Pelargoniums are planted together with other plants of South African origin such as Strelitzia reginae, and bulbous species such as Veltheimia bracteata, Haemanthus coccineus and Cyrtanthus falcatus. The landscaping is an area composed of rock work with very free-draining soil and the plants grow over the rocks and over each other. The planting is intended to show the plants with their associated species.

\section{Temperate Palm House}

The landscaping and planting in this recently restored Victorian glasshouse has been designed to reflect the evolutionary relationships between plants. Three pelargonium species were planted with members of the Crassulaceae and Compositae in 2005 as these families are considered to be close to Geraniaceae in evolutionary terms. The planting and light conditions are not ideal for the pelargoniums planted here, being rather damp and shaded. P. glechomoides, however, does well here, and it is planned that $P$. transvaalense, which requires more shade and damp than most pelargoniums, will be planted in the near future.

The Palm House also has two long stone benches on which potted plants are displayed and pelargoniums from the potted collection are ideal candidates for this area. 
Other plants used for display on these benches include orchids, vireya and maddeni rhododendrons and citrus plants. Plants are of a suitable size to carry to the benches when they are in full flower, where they provide very bright flowers and scented foliage for a good display. When the flowers have gone over, the plants are replaced. While there are almost always plants from the RBGE potted collection to dress these benches, many of the winter-growing and -flowering pelargoniums such as $P$. cortusina, $P$. echinatum, P. pulverulentum (Fig. 11), and P. lobatum (Fig. 12) provide a welcome display through the sometimes 'lean' (for flowers) months of winter. There is an educational role for these plants as well. This glasshouse is the main entrance for the glasshouse range so all glasshouse visitors pass through this house and most visit the stone benches first for its eye-catching display. The plants are clearly labeled and here the public can find genera with which they are familiar, which is often welcome, when there are so many unfamiliar plants in the glasshouse range. They can also find varieties, forms and species of pelargoniums which they may not previously have known, but which are commercially available, and therefore they know that they will be able to grow them at home.
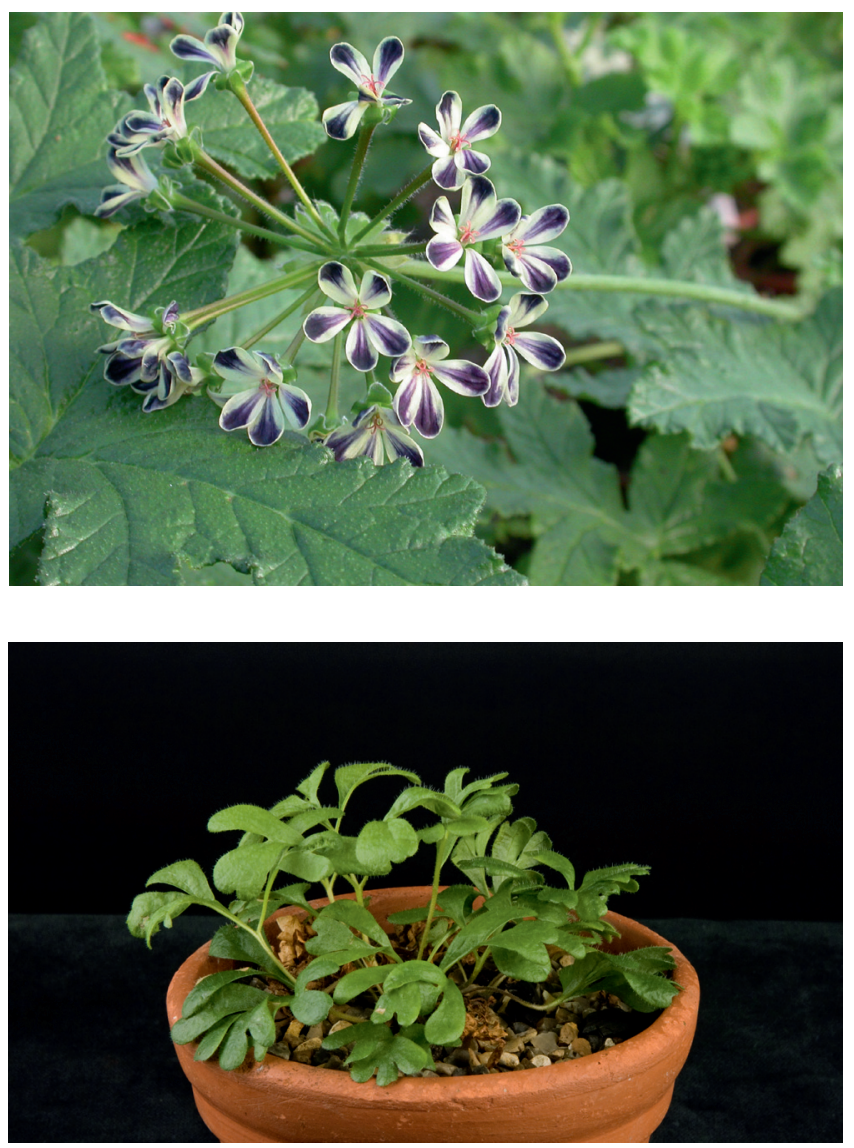

Fig. 12 Pelargonium lobatum. Photo: Kate Hughes.

Fig. 13 Pelargonium fergusoniae. Photo: Lynsey Wilson. 


\section{Alpine Courtyard}

Here $P$. endlicherianum is planted in a raised border with a free-draining soil with other alpine plants such as Penstemon montanus, Parahebe lyallii, and Phlox douglasii. Protection is provided in winter as previously described (Fig. 10).

\section{CULTIVATION}

Pelargoniums, particularly the species, grow best in standard terracotta pots. This is because they do not like to 'sit wet', that is with a lot of water in the root area. Terracotta is a porous material in contrast to plastic, and therefore provides better drainage of excess water and allows for greater movement of air around the roots. It is also felt to be 'warmer' because it tends to be drier than plastic which is good for root growth. Plastic pots are suitable for the strong and fast growing cultivars and species (for example those in section Pelargonium) which take up water quickly and have a vigorous root system.

\section{Compost}

The compost used at RBGE is a free-draining, gritty mixture made up of $60 \%$ John Innes No. 2, or No. 3 if potting-on mature plants, $20 \%$ Propagation bark (finely milled pine bark with an average dimension of $2-7 \mathrm{~mm}$ ), $10 \%$ Flint Chick grit (average $2 \mathrm{~mm}$ diameter), $5 \%$ horticultural sand, $5 \%$ horticultural charcoal. $80 \mathrm{~g}$ of Osmocote slowrelease plant food per 100 litres of compost is mixed in. This mixture provides a free-draining medium which still retains nutrients. The milled pine bark retains some moisture and prevents the loam from 'setting'. A dense loam can set and become hard which can limit growth and root movement through the compost.

A separate mix for the tuberous, caudiciform, succulent and other winter-growing species (sections Hoarea, Figs. 13 and 14, Otidia, Fig. 15, Polyactium, Fig. 12, Ligularia,

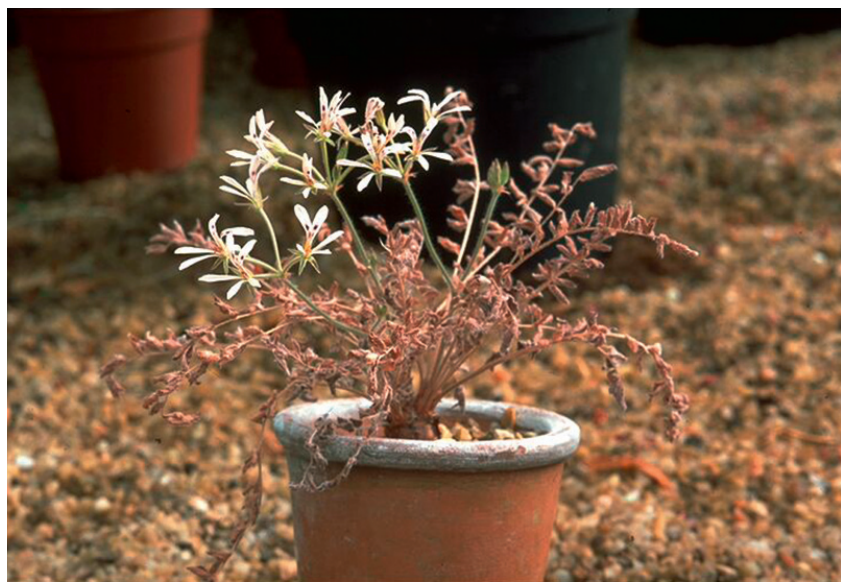

Fig. 14 Pelargonium carolihenrici; like other species in section Hoarea the leaves die down before the flowers emerge. Photo: Debbie White. 


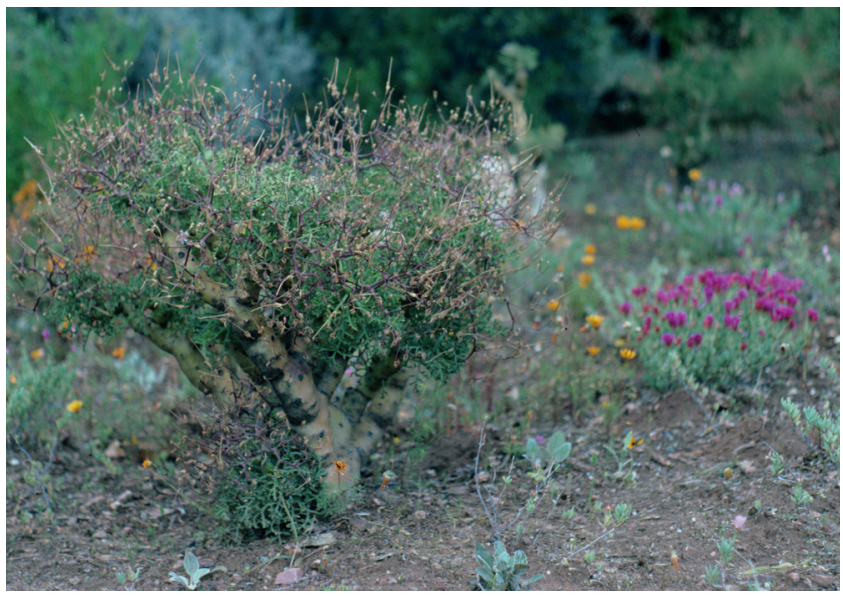

Fig. 15 Pelargonium carnosum growing in its native environment at National Botanical Garden, Worcester, South Africa. Photo: Kate Hughes.

Jenkinsonia and Cortusina) is made in which the propagation bark in the mixture listed above is omitted and extra John Innes and sand are added. This is because these species prefer very free-draining compost. After potting up they are top-dressed with Flint Hen Grit. This helps to keep moisture in the pot during the growing season as these species do not like to dry out at this time. It also prevents water from 'sitting' around the neck of the plant which can cause the tubers to rot. Once plants start to rot from being too wet, it is very difficult to reverse the damage. So prevention with a free-draining medium and top-dressing of grit plus careful watering is essential.

\section{Irrigation}

In summer the summer-growing species and cultivars can be watered freely, as the surface of the compost in the pot dries out, with normal tap water. This is because the plants are growing vigorously in the warm, light conditions and, if the glasshouse is well-ventilated, moisture is also lost through air movement. A lance with a single narrow nozzle is used, with the water turned to low pressure, to prevent the compost being blown out of the pot and causing excessive drenching to the benches.

In winter, water is stored in a plastic water butt in order to reach ambient temperature and a watering can is used to irrigate the plants. This means that the temperature of the pot and roots does not fluctuate as much as if cold tap water from the mains was used. The application of very cold water from the mains tap can stress plant roots. Stress weakens plant roots and can contribute to the entry of pests and diseases. The use of a watering can to 'spot water', that is to water individual pots as necessary, helps to minimize the amount of excess water sitting on the benches and in the pots. Plants should be watered when the compost has dried out slightly as they are not actively growing and over-watering at this time increases dampness. Excessive dampness and cold encourages botrytis mould (see Pests and Diseases below). 
The winter-growing species must be watered as the surface of the compost dries out when they are in growth. While they are drought tolerant plants, it is important not to let them dry out completely when in growth as the foliage wilts readily causing damage to some of the leaves for the rest of the season. This weakens the plants increasing their susceptibility to botrytis and reducing their photosynthetic capacity in an already short growing season. These species do not 'bounce back' from drying out in the same way that the sub-shrubby species do.

In Edinburgh many plants in section Hoarea will keep their leaves for longer than they would in the wild because water is more available and temperatures and light levels are lower. This means that they will often flower while green leaves can still be seen. It is important to reduce, but not stop, watering winter-growing species in March if flower stems are appearing from the crowns, even if plants appear to be in full growth. However, if they are watered when the flower buds open they will not take up the water and this can cause the small tuber to rot. When flowers open, watering should cease and the plants should be allowed to die back naturally.

If winter-growing plants are showing signs of dying back, with yellowing but not shrivelled leaves, watering should cease.

\section{Plant nutrition}

While it is traditional not to feed glasshouse-grown plants through the winter months, it has been found to be beneficial to feed pelargoniums all year round although the levels of feed applied should be varied from winter to summer.

September to February: Summer-growing species and cultivars are fed with a balanced (NPK 1:1:1) chemical liquid feed at 1/3 strength every 4-6 weeks. Wintergrowing species are fed with half strength, Maxicrop liquid seaweed feed twice monthly as they come into growth. Once all the leaves have emerged and they are growing strongly, they are also fed with the balanced chemical feed in the same way as the summer-growing species.

February to April: Summer-growing species and cultivars are fed with half or full strength balanced feed once every four weeks. Winter-growing species are dying back at this time and are not fed at all.

May to September: Summer-growing species are fed with either a high potassium (NPK 2:1:4) or balanced (1:1:1) feed once or twice monthly depending on growth and the condition of the plants.

\section{Pruning}

Most pelargoniums are fairly small plants with the largest in the collection at RBGE being $P$. papilionaceum which grows up to $2 \mathrm{~m}$. However, when some of the larger species and cultivars such as $P$. papilionaceum, $P$. hispidum, $P$. tabulare, and $P$. 'Purple Unique' are several years old some branches may need to be removed or cut back. 
Pelargoniums tend to produce a lot of foliage in the warm and well-fed conditions of the glasshouse and are cut back as often as necessary to keep the shape of the plants and allow air circulation. This entails the removal of about one third of the plant. The best time to do this is late summer or autumn when the plant has finished flowering but before the low light levels of winter begin to slow growth down. This means that they can 'sit small' for winter, providing minimal foliage for pests to overwinter on and enabling good air circulation.

All of the shrubby and scrambling species and cultivar plants will grow in to a more practical and pleasing shape if regularly 'pinched out'. Pinching out will also remove the need to cut back as described above. They will also flower on more compact plants which means that they make better display plants. "...removing the growing point or tip of each stem is an essential part of good geranium culture, probably the most essential" (Shellard, 1981).

Commercially sold plants are regularly pinched out in order to form small compact plants with a selection of flower buds for easy transportation to shows, sale by mail order, and to look good on the garden centre shelf (H. Bainbridge pers. comm.). When growth begins around February as light levels gradually increase, the growing tip of the main shoot is 'stopped' or pinched out, leaving the fully formed leaves. Side shoots will grow and develop after this first 'stop' and the tips of these should be removed from mid-April onwards. As flower buds form, the shoot which follows a set of buds is pinched out, not the flowering shoot. This pinching out removes the apical shoot, causing the leaf-producing hormone, auxin, to be produced in the side shoots instead. These shoots then begin to grow and flower buds form on them. This creates a plant which is rounded, compact and bushy, and flower buds are produced all around the crown of the plant. If plants are not pinched out, the leader, or apical shoot, will elongate, flowers will form at the end of the leader shoot and, once these flowers have finished, flowers may form on some of the other shoots once they have elongated. The overall effect will be one of a very straggly, sparsely flowering plant which takes up more space than it merits.

The geophytic species (sections Hoarea, Magnistipulacea and Polyactium) which grow from tubers and die down in spring never need to be pruned or pinched out. The succulent species (sections Otidia, Cortusina, and Ligularia) can form large branches over time but removing these spoils the shape of the plant and should be done with care. The shoots that are removed in this way can be usefully used for propagation.

\section{Other notes on cultivation}

Regular removal of yellow leaves is essential. This is not only for aesthetic reasons but also because they prevent light and air movement around healthy shoots which can encourage fungal diseases. It is also important to keep the benches and pots free from weeds particularly because some glasshouse weeds such as chickweed (Stellaria media) provide a host for pests such as whitefly and fungal rusts. 


\section{Pests and diseases}

There are a number of pests and diseases which commonly affect pelargoniums, especially when grown as a monoculture. These are relatively easily dealt with if treated regularly.

Whitefly: Bemisia tabaci or Trialeurodes vaporariorum is the most prevalent and widespread pest of pelargoniums. The warm, dry conditions which suit pelargoniums are also favored by whitefly as well and there seem to be some species and cultivars which are particularly prone to attack especially in sections Ciconium, Pelargonium and Polyactium. Other sections seem to be barely affected by whitefly, such as Glaucophyllum, which has now been amalgamated with section Pelargonium (Bakker et al., 1999). The leaves of the species in this section have, as the name suggests, a thick, hairless, glaucous, lamina which appears to have a protective function. Whitefly are sap-sucking insects which weaken the plant through this action and multiply extremely rapidly, covering the undersides of new leaves with adults, eggs and scales (young nymphs which have settled to feed) and a sticky honeydew excretion. The honeydew also drops on to the leaves and also on surrounding plants and a sooty mould (Cladosporum sp.) grows on these sugary droplets. This not only looks unsightly but also prevents light from reaching the leaf surface, reducing the plant's photosynthetic capacity.

Whitefly can be treated with a contact or systemic insectide. A contact insecticide kills the pest by coming into contact with it at the time of application while a systemic insecticide is one which is applied to the plant pot where it is taken up by the plant and kills the pest when ingested via the plant sap. At RBGE, whitefly control has been most successful when treated with two applications, six weeks apart, of an imidocloprid-based systemic insecticide. At the first sight of any whitefly after this point, an insectidal soap such as Savona is applied immediately. The insectidal soap blocks the breathing tubes of the whitefly and as it is a contact insecticide it means that the pests do not build up resistance to it. This can always be a risk with the repeated use of systemic insecticides.

Biological control with the parasitic wasp Encarsia formosa, which can be very effective in glasshouses, is not useful against whitefly on pelargoniums because the volatile oils in the foliage are repellent to the wasps (H. Bainbridge pers. comm.)

Aphids: P. sidoides is particularly affected by an unspecified green aphid (Aphididae) commonly known as greenfly. Infestations are usually limited to this species and P. gibbosum. These are easily treated by squashing by hand or by the application of an insectidal soap.

Carnation tortrix moth: Cacoecimorpha pronubana has also been a problem in the RBGE collection in recent years. Bright green caterpillars curl young leaves around them and spin a silk webbing to protect themselves while they feed on the leaves until ready to pupate (Buczacki and Harris, 1998). The best treatment for these has been found to be constant examination of the plants for caterpillars and squashing on sight. A biological control called Dipel DF containing the bacteria Bacillus thuringiensis var. kurstaki has also been used but has been found to be limited in its effectiveness. 
The reason is that the control has to come into direct contact with the caterpillars to be effective and these are usually well protected by the leaves that they have curled around themselves.

Botrytis: Botrytis cinerea, commonly known as botrytis mould, thrives when light levels and outside temperatures drop in the winter months resulting in dampness within the glasshouse. The section Hoarea has been particularly affected in past winters. However, this problem has been removed by the installation of a simple office fan positioned over the winter growing species and switched on for a minimum of three hours per day. The fan dries the leaf surfaces where droplets of water may lie and provide a host for botrytis. It also causes air movement which prevents the establishment of botrytis spores.

\section{PROPAGATION BY SEED AND CUTTINGS}

Pelargonium species and cultivars are commonly propagated vegetatively because they root very easily from cuttings. The features of the cultivated varieties will only be preserved by vegetative increase and so taking cuttings is the only option for the propagation of these plants. However, many species germinate readily from seed if sown as noted below.

\section{Seed}

Some species hybridise freely if grown together, so it is important to bag the flowers if guaranteed true seed is required. Seed should be collected fresh and stored with the plumes intact. The plumes are the curled 'tails' which are attached to the mericarp, the seed lies within this structure. They can be stored in a clean, cool and dry place, such as the shelf of a cupboard, as long as the packets are kept away from extreme temperatures and damp.

For sowing seed, John Innes seed grade loam is sieved with a $2 \mathrm{~mm}$ sieve and mixed with chick grit at a ratio of 3:1. This makes a soft and free-draining, low-nutrient mixture. The pot is filled and the surface tamped down. On top of this is placed a $2-3 \mathrm{~mm}$ layer of chick grit. Seeds are sown individually by holding the plume and placing the point of the mericarp into the layer of chick grit and inserting to a depth of $2 \mathrm{~mm}$. A $70 \mathrm{~mm}$ square pot can accommodate up to 15 seeds but 12 is an ideal number. This gives each seed space to develop.

The pot of seeds must be watered with a fine rose so that the seeds are not disturbed. To watch the tension within the twisted plumes unwind, as they absorb water and drive the pointed seeds further into the substrate, must be one of the most enjoyable sights for the propagator! The surface of the pots appears to move, with some plumes moving in unison with their neighbours, while others catch onto each other inhibiting their circular journey. It is so unusual to see plants move of their own accord that, as a grower, it can be exciting to be reminded that sometimes they do. 
Pots of seed must be placed on the benches where mature plants are growing rather than in a heated propagation bench as they require a period of cold at night to trigger germination (F. Powrie, pers. comm.). If the seed is fresh and watered regularly, many species will germinate within approximately 14 days. Seedlings are potted-up into the potting compost described earlier made with John Innes No.1 when they have several true leaves and are growing strongly. A very weak feed of Maxicrop seaweed plant food, several days before removal from the seed pot, can strengthen plants prior to the trauma of pricking out.

\section{Cuttings}

The propagation of pelargoniums by cuttings is common and well-documented in numerous books such as Shellard (1971) relating to the cultivation of pelargonium cultivars. However, some key points for success are noted below:

- Plants will root better if in good health and free from common pests and diseases such as viruses and whitefly.

- The best months for rooting cuttings are August-October, although many will root from February-November.

- Regal and Unique cultivars will root best when taken in November.

- Zonal cultivars will root best when taken from April to September.

- Angel cultivars will root in winter but not when taken in May to June.

- A 1:1 mix of perlite and finely milled pine bark provides an excellent rooting medium.

- Terracotta pots are recommended for rooting cuttings

- Hormone rooting powder or liquid is useful for its fungicidal properties to prevent stem rot, and it's use is recommended

- Once inserted, pots are placed on a propagation bench heated to $25^{\circ} \mathrm{C}$ and misted regularly or watered from a watering can with a fine rose

- Cuttings are less inclined to rot off if the medium has time to dry out slightly between waterings

- Rooting is improved if water has been heated to the ambient temperature of the glasshouse before misting

\section{ECONOMIC USES}

Pelargoniums are grown worldwide for their commercial use as display plants, seeds for the nursery industry and extracts for the perfumery and medicinal industries.

Pelargoniums became popular as glasshouse and summer bedding plants in the 1800s, particularly after the tax on glass was lifted in 1851 (Lis-Balchin, 2002), when hybridizing and selection for flower colour and size became very popular. They were popularly known as 'Geraniums' then because of their similarity to hardy geraniums and the popular name has stuck. At this time highly sought after or new varieties were 
sold for a lot of money. Production is now widespread and pelargoniums fetch the same prices as other plants, such as fuchsias and petunias, sold for bedding and summer use. James (2002) writes that approximately 120 million plants are grown annually in the USA, 70 million in Germany and 2 million in Britain. France and Holland are also big producers of these plants. Often purchasers of these plants tend to grow them for summer displays, discard them in autumn and buy fresh plants the following year. While this culture continues, the pelargonium industry will be buoyant.

An extract from several pelargonium species called Geranium oil is widely used in perfumery and for aromatherapy. It is among the 20 most used volatile oils extracted from plants and annual world production is worth nearly $£ 7,000,000$ (Williams and Harborne, 2002). The oil is steam-distilled from the leaves of $P$. graveolens, $P$. capitatum, and $P$. radens.

Kolodziej (2002) describes the use of $P$. reniforme and $P$. sidoides by the local native population in southern Africa, where it is known as 'umckaloabo' and is used to treat respiratory and lung problems. Kolodziej has researched the efficacy of these treatments and the results indicate that extracts from the roots of these plants can relieve such problems and these extracts are available commercially. Natural Products Magazine (Natural Products Magazine, 2009) regularly features a product distributed by Medicherb sold under the name of 'Pelargonium' which is described as 'concentrated dried extract of Pelargonium sidoides'. Publicity on the website states that it is for the treatment of coughs, colds and sore throats.

\section{CONCLUSION}

Although both the public and horticulturists are familiar with the widely grown cultivars and species of pelargonium, in my opinion there are many less familiar species which are interesting and well worth growing. Those in sections Otidia, Hoarea, Jenkinsonia and Ligularia are fascinating for the variety shown in their growth habits and in their ability to survive extreme heat and drought. Many of the plants in these groups also have an aesthetic appeal when flowering. The explosive flower heads of Pelargonium oblongatum (Fig. 16) which shoot up from the crown of huge fleshy leaves are fascinating too. Others are interesting for their flower colour and shape, such as $P$. triste (Fig. 17), P. pulverulentum (Fig. 11), and P. lobatum (Fig. 12). There are three species with cut-leaved petals, $P$. caffrum (Fig. 18), P. schizopetalum (Fig. 19), and P. bowkeri (Fig. $20)$. The flower shape of these species is extremely unusual with the finely divided petals and the colour is often subtle or bicoloured in contrast to the bolder and

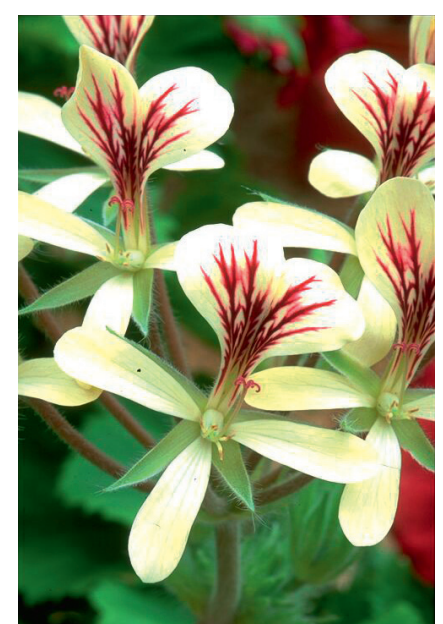

Fig. 16 Pelargonium oblongatum. Photo: Debbie White. 


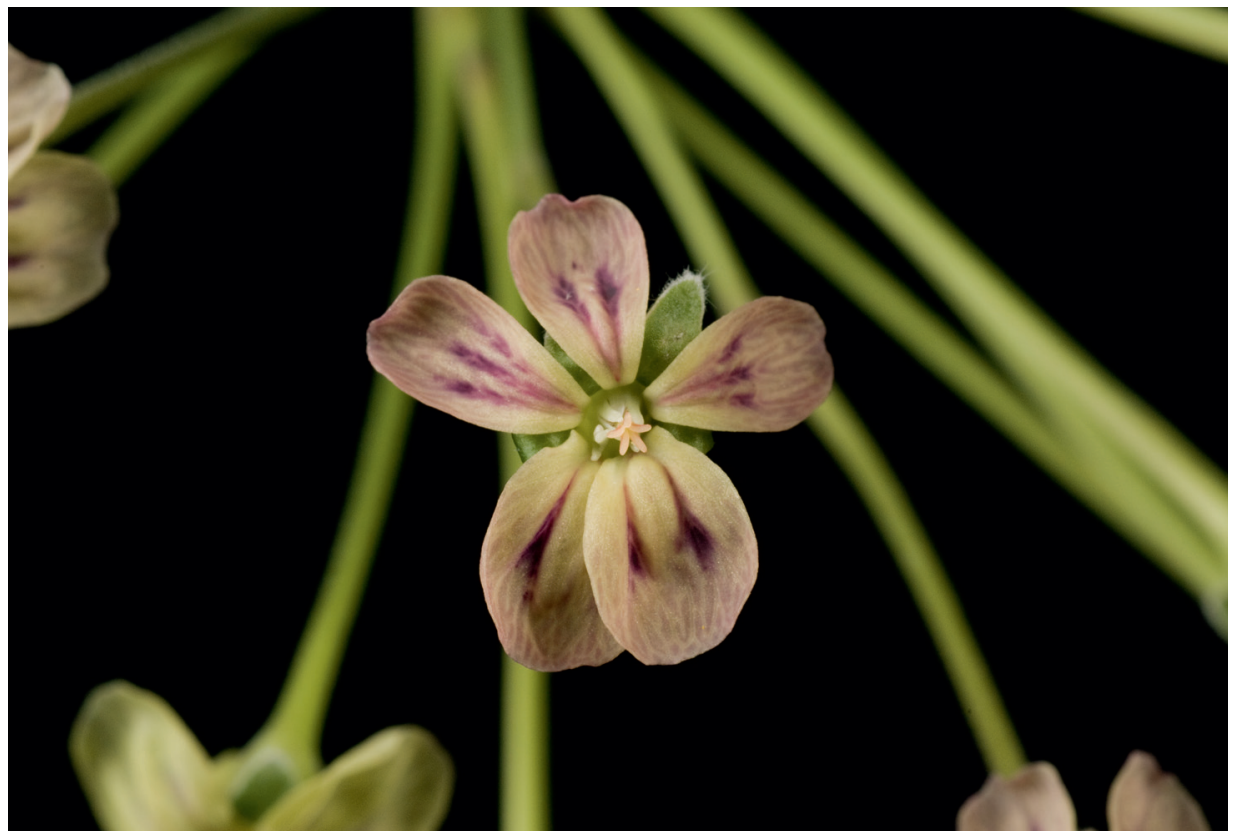

Fig. 17 Pelargonium triste, 'triste' comes from the latin for 'sad' referring to the colour of the flower. Photo: Lynsey Wilson.

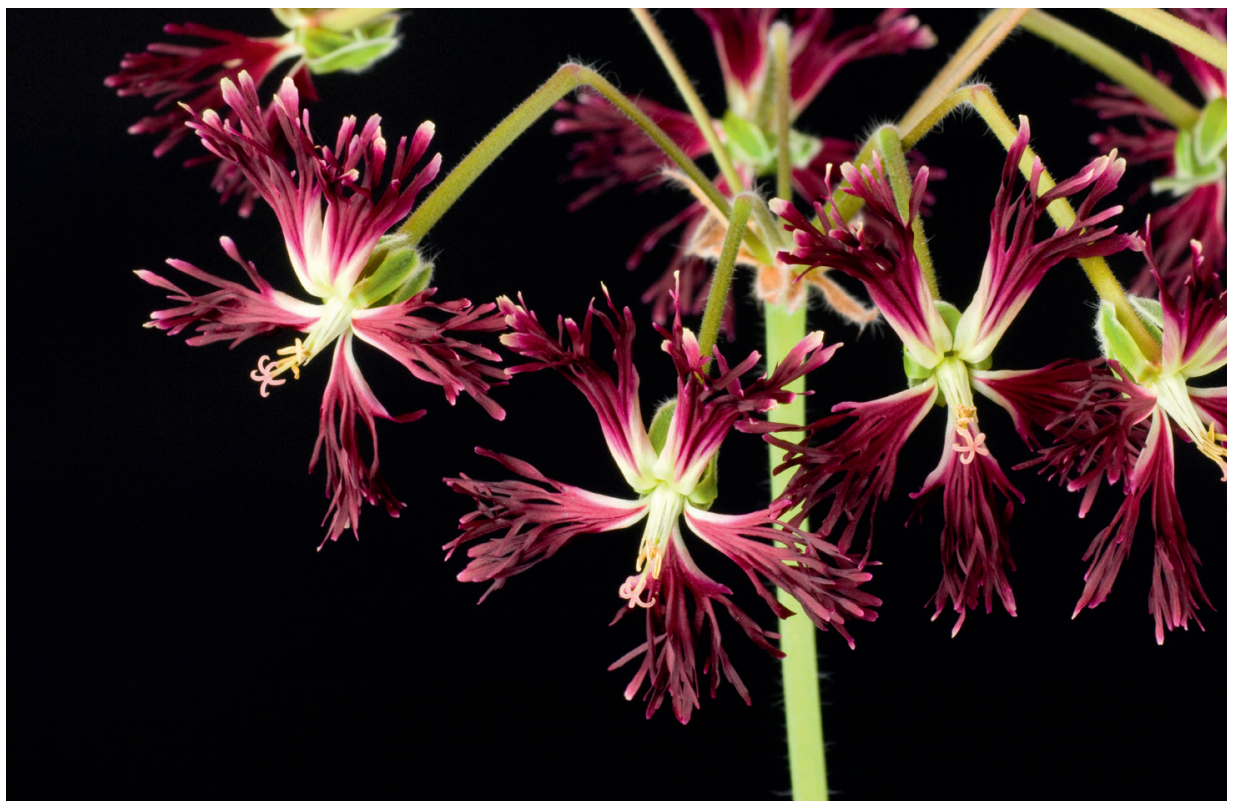

Fig. 18 Pelargonium caffrum. Photo: Lynsey Wilson. 


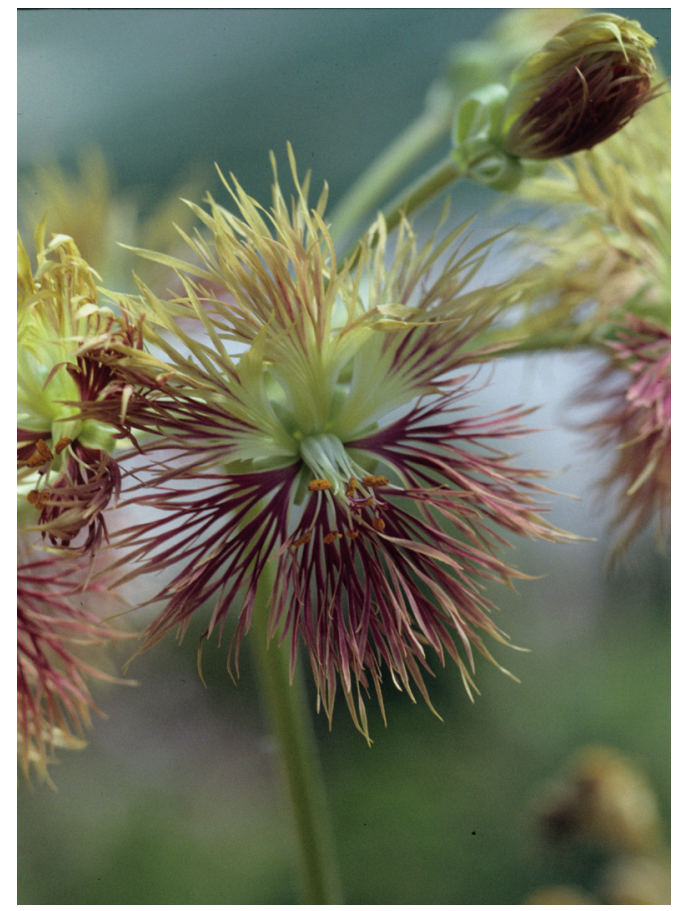

Fig. 19 Pelargonium schizopetalum. Photo: Kate Hughes.

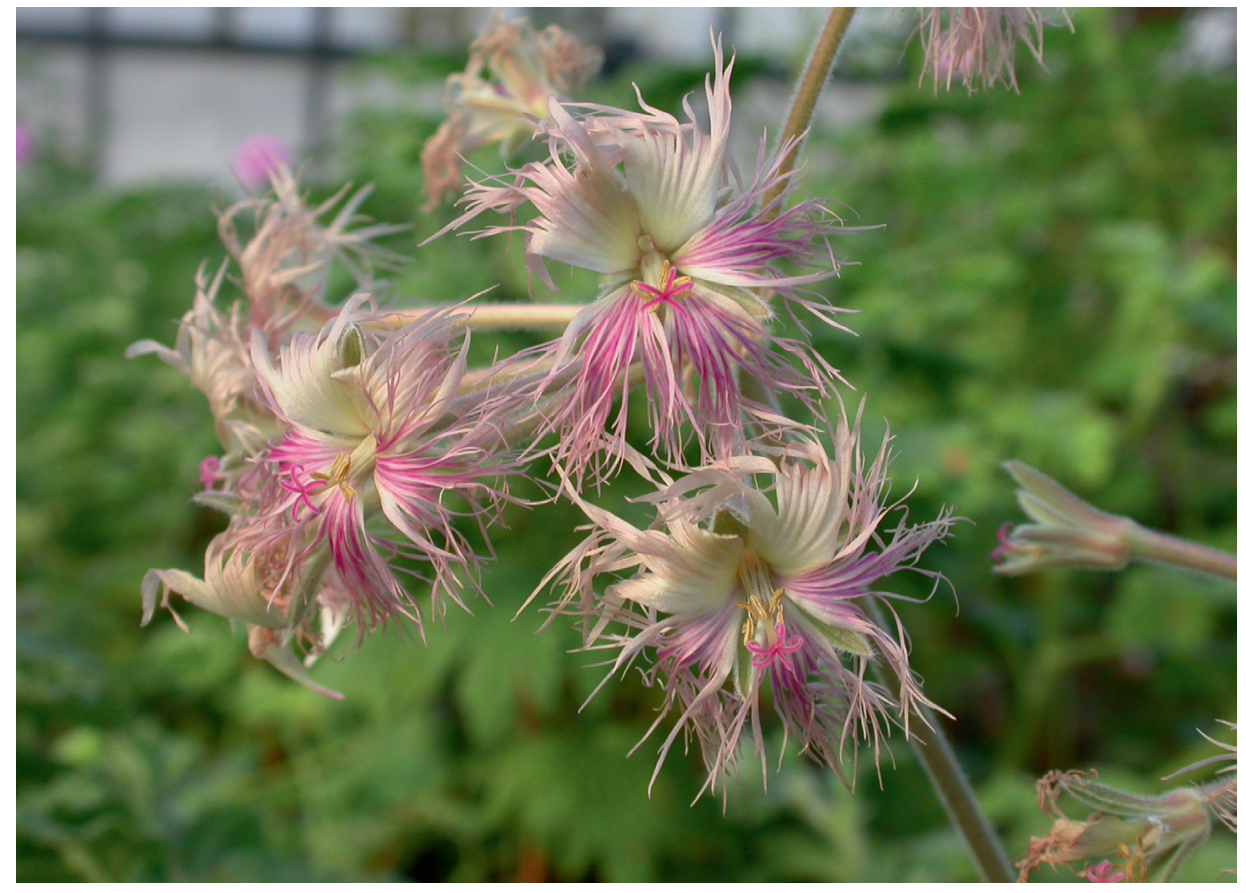

Fig. 20 Pelargonium bowkeri. Photo: Kate Hughes. 
brighter single colours of the more familiar cultivars. These types of flowers may not hold an appeal for the mass market but when seen, always elicit expressions of surprise and interest.

Many of these plants are not difficult to grow given the right conditions, namely the protection of a frost free, well-ventilated glasshouse, and deserve to be more widely grown.

\section{ACKNOWLEDGEMENTS}

I would like to thank Fiona Powrie, Landscape Gardener and Horticulturist in Paarl, South Africa for sharing her knowledge of pelargoniums and the South African flora with me. I would also like to thank Helen Bainbridge of Fir Trees Pelargoniums, Yorkshire for sharing her knowledge of growing pelargoniums commercially.

Many thanks are also due to Mary Gibby for providing up to date taxonomic information for the sections of the genus, for the first paragraph of the third section of this paper and also for reviewing the text.

\section{REFERENCES}

BAKKER, F.T., CULHAM, A., \& GIBBY, M. (1999). Phylogenetics and diversification in Pelargonium. In: HOLLINGSWORTH, P. M. BATEMAN, R. M. and GORNALL, R. J. (Eds). Molecular systematic and plant evolution. London: Taylor and Francis, pp. 353-374.

BAKKER, F.T., CULHAM, A., PANKHURST, C.E. \& GIBBY, M. (2000). Mitochondrial and chloroplast DNA based phylogeny of Pelargonium (Geraniaceae). American Journal of Botany 87: 727-734.

BUCZACKI, S. T. \& HARRIS, K. M. (1998). Pests, Diseases and Disorders of Garden Plants. London: Harper Collins Publishers Ltd.

JAMES, J. (2002) Cultivations and sales of Pelargonium plants for ornamental use in the UK and worldwide. In: LIS-BALCHIN, M. (Ed). Geranium and Pelargonium. London: Taylor and Francis, pp 82-90.

KOLODZIEJ, H. (2002). Pelargonium reniforme and Pelargonium sidoides: their botany, chemistry and medicinal use. In: LIS-BALCHIN, M. (Ed). Geranium and Pelargonium. London: Taylor and Francis, pp 262-290.

MILLER, D. (1996). Pelargoniums: a gardener's guide to the species and their hybrids and cultivars. London: B.T. Batsford Ltd.

Natural Products Magazine (2009). Available at: Naturalproductsonline.co.uk (Accessed: February 2009)

WILLIAMS, C.A. \& HARBORNE, J.B. (2002). Phytochemistry of the genus Pelargonium. In: LIS-BALCHIN, M. (Ed). Geranium and Pelargonium. London: Taylor and Francis, pp 99-117.

SHELLARD, A. (1981). Geraniums for home and garden. Devon: David and Charles Ltd.

VAN DER WALT, J. J. A. \& WARD-HILHORST, E. (1977). Pelargoniums of Southern Africa. South Africa: Purnell \& Sons S.A. (Pty) Ltd. 